表 2 新潟県中越地震との比較

\begin{tabular}{|c|c|c|}
\hline 地震の名称 & 東北地方太平洋沖地震 & 新潟県中越地震 \\
\hline 地震の種類 & 海溝型地震 & 直下型地震 \\
\hline 発生日時 & $\begin{array}{l}2011 \text { 年 } 3 \text { 月 } 11 \text { 日 } \\
14 \text { 時 } 46 \text { 分頃 }\end{array}$ & $\begin{array}{c}2004 \text { 年 } 10 \text { 月 } 23 \text { 日 } \\
17 \text { 時 } 56 \text { 分頃 }\end{array}$ \\
\hline 震源の深さ & 約 $24 \mathrm{~km}$ & 約 $13 \mathrm{~km}$ \\
\hline マグニチュード & Mw9.0 & Mw6.6 \\
\hline 最大震度 & 震度 7 & 震度 7 \\
\hline $\begin{array}{c}\text { 地震動の } \\
\text { 最大継続時間 }\end{array}$ & 200 秒以上 & $20 \sim 30$ 秒程度 \\
\hline $\begin{array}{l}\text { 通行止めの } \\
\text { 路線・区間 }\end{array}$ & $\begin{array}{c}35 \text { 路線 } \\
\text { 約 } 2,300 \mathrm{~km} \text { 区間 }\end{array}$ & $\begin{array}{c}6 \text { 路線 } \\
\text { 約 } 580 \mathrm{~km} \text { 区間 }\end{array}$ \\
\hline $\begin{array}{l}\text { 余震の回数 } \\
\text { (震度 } 5 \text { 以上) }\end{array}$ & $\begin{array}{c}32 \text { 回 } \\
3.11 \sim 5.10 \quad(60 \text { 日間 })\end{array}$ & $\begin{array}{c}17 \text { 回 } \\
10.23 \sim 12.22 \text { (60日間) }\end{array}$ \\
\hline 主な被害の内容 & 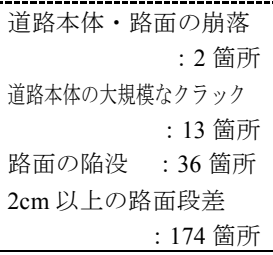 & $\begin{array}{r}\text { 大規模な盛土崩落 } \\
\qquad 3 \text { 箇所 }\end{array}$ \\
\hline
\end{tabular}

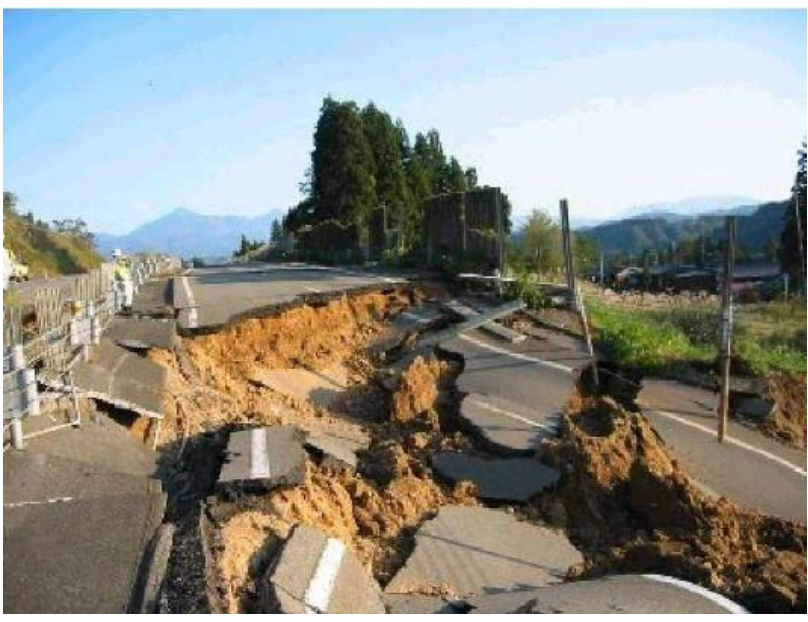

写真 1 新潟県中越地震の土工部の被害状況 ${ }^{1)}$

を記録している。ただし, 震度 1 以上が観測された範囲 (図 1）を見てみると，中越地震では，東は東北から西は近畿 までの影響に留まったが，東北地方太平洋沖地震では，東 は北海道から西は九州にまで影響が及んでおり, 今回の地 震の大きさを改めて確認寸ることができる。そのため，一 時的に通行止めとなった路線・区間も，中越地震では 6 路 線約 $580 \mathrm{~km}$ 区間であったのに対して，東北地方太平洋沖 地震では 35 路線約 $2,300 \mathrm{~km}$ 区間にも及んでいる。また, 本震後の余震の回数については, 地震発生から 2 ケ月 $(60$ 日）間の震度 5 以上の余震の発生回数を比較してみると, 中越地震では 17 回だったのに対し東北地方太平洋沖地震 では 32 回にも達している。

以上のことから, 地震被害の特徴が同様であった中越地 震と比較しても, 今回の東北地方太平洋沖地震が，いかに 巨大な地震であったかがうかがえる。
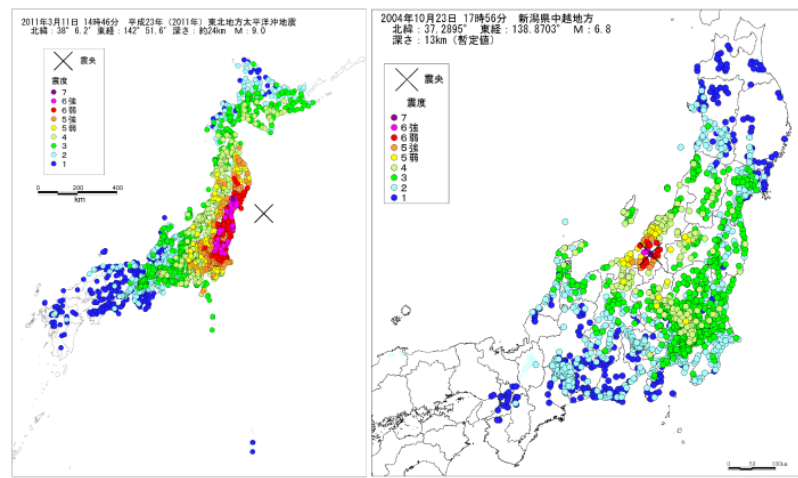

図 1 新潟県中越地震との震度分布の比較2)

(左図 : 東北地方太平洋沖地震, 右図 : 新潟県中越地震)

\section{3. 高速道路の被害と復旧の状況について}

地震発生直後から, NEXCO 東日本が管理する高速自動 車国道および一般国道自動車専用道路 (以下,「高速道路」 とする）の 35 路線, 約 $2,300 \mathrm{~km}$, 供用中路線の約 $65 \%$ に おいて通行止めを実施した。その後，緊急点検を行った結 果，20 路線，約 $870 \mathrm{~km}$ 区間において交通の支障となる被 害が確認された（表 3, 図 2)。そのため，緊急点検にあ わせて, 簡易舗装補修材や土のうを用いて路面段差部の仮 復旧注1) を行うことで，東北自動車道，常磐自動車道，般 越自動車道などの主要路線を中心に, 地震発生翌日の 3 月 12 日早朝までに, 緊急車両の通行を可能とした。そして, 地震発生から約 20 時間後の 3 月 12 日 11 時以降, 順次, 公安委員会による緊急交通路としての指定がなされ，最大 で 6 路線，約 $583 \mathrm{~km}$ 区間について，緊急車両の通行や物 資の輸送に利用された。また，仮復旧に続き，応急復旧注2 を順次完了させ開通させるなどし, 3 月 22 日時点までに, 約 $813 \mathrm{~km}$ 区間の一般車両の通行を可能とした。最終的に, 東北自動車道を全線一般開放したのは，地震発生から 13 日後の 3 月 24 日 6 時となった。これにより，被害を受け た延べ約 $870 \mathrm{~km}$ 区間の高速道路の約 93\%について，応急 復旧が完了することとなった。

\section{4. 各路線における被害と復旧の状況について}

高速道路の被害の状況は，東北自動車道郡山 IC を中心 に被害が集中した。盛土損傷箇所のうち, 盛土崩落と見な された箇所は 21 箇所にも及んだ。ただし，暫定 2 車線区 間であった仙台北部道路の盛土損傷 2 箇所は，仮復旧に 45 時間要したものの, 山形自動車道の盛土損傷 1 箇所を 除いたほかの箇所は，地震発生から 20 時間後には，緊急 通行路として仮復旧を終えている。

表 4 に, 各路線における交通の障害となる被害の発生状 況について示す。

注1) 緊急車両の通行を可能とするために実施する復旧のこと。

注2) 仮復旧に続き, 一般車両の通行を出来うる限り早期に可能と するために実施する復旧のこと。そのため, 各県警察による 速度規制，車線規制が実施される。 
表 3 交通の支障となる被害を受けた路線・区間 ${ }^{3)}$

\begin{tabular}{|c|c|c|}
\hline 路線 & & 行間 \\
\hline 東北自動車道 & 347.1 & km 区間 \\
\hline 釜石自動車道 & 7.7 & $\mathrm{~km}$ 区間 \\
\hline 山形自動車道 & 28.1 & $\mathrm{~km}$ 区間 \\
\hline 東北中央自動車道 & 6.6 & $\mathrm{~km}$ 区間 \\
\hline 磐越自動車道 & 85.5 & $\mathrm{~km}$ 区間 \\
\hline 関越自動車道 & 11.8 & $\mathrm{~km}$ 区間 \\
\hline 上信越自動車道 & 15.0 & $\mathrm{~km}$ 区間 \\
\hline 常磐自動車道* & 166.4 & $\mathrm{~km}$ 区間 \\
\hline 館山自動車道 & 7.5 & $\mathrm{~km}$ 区間 \\
\hline 東関東自動車道 & 63.1 & $\mathrm{~km}$ 区間 \\
\hline 東京外環自動車道 & 0.9 & $\mathrm{~km}$ 区間 \\
\hline 北関東自動車道 & 45.8 & $\mathrm{~km}$ 区間 \\
\hline 仙台北部道路 & 11.8 & $\mathrm{~km}$ 区間 \\
\hline 仙台東部道路 & 18.5 & $\mathrm{~km}$ 区間 \\
\hline 三陸自動車道 & 4.0 & $\mathrm{~km}$ 区間 \\
\hline 東水戸道路 & 10.2 & $\mathrm{~km}$ 区間 \\
\hline 京葉道路 & 6.4 & $\mathrm{~km}$ 区間 \\
\hline 東京湾アクアライン & 15.1 & $\mathrm{~km}$ 区間 \\
\hline 富津館山道路 & 4.1 & $\mathrm{~km}$ 区間 \\
\hline 圈央道 & 14.2 & $\mathrm{~km}$ 区間 \\
\hline 20 路線 & 869.8 & km 区間 \\
\hline
\end{tabular}

* 震災直後, 福島県の原子力発電所事故の影響で立ち入りができなかった 常磐自動車道いわき中央 IC〜常磐富岡 IC 間（43.0km）については，詳 細な被害状況は確認できなかった。

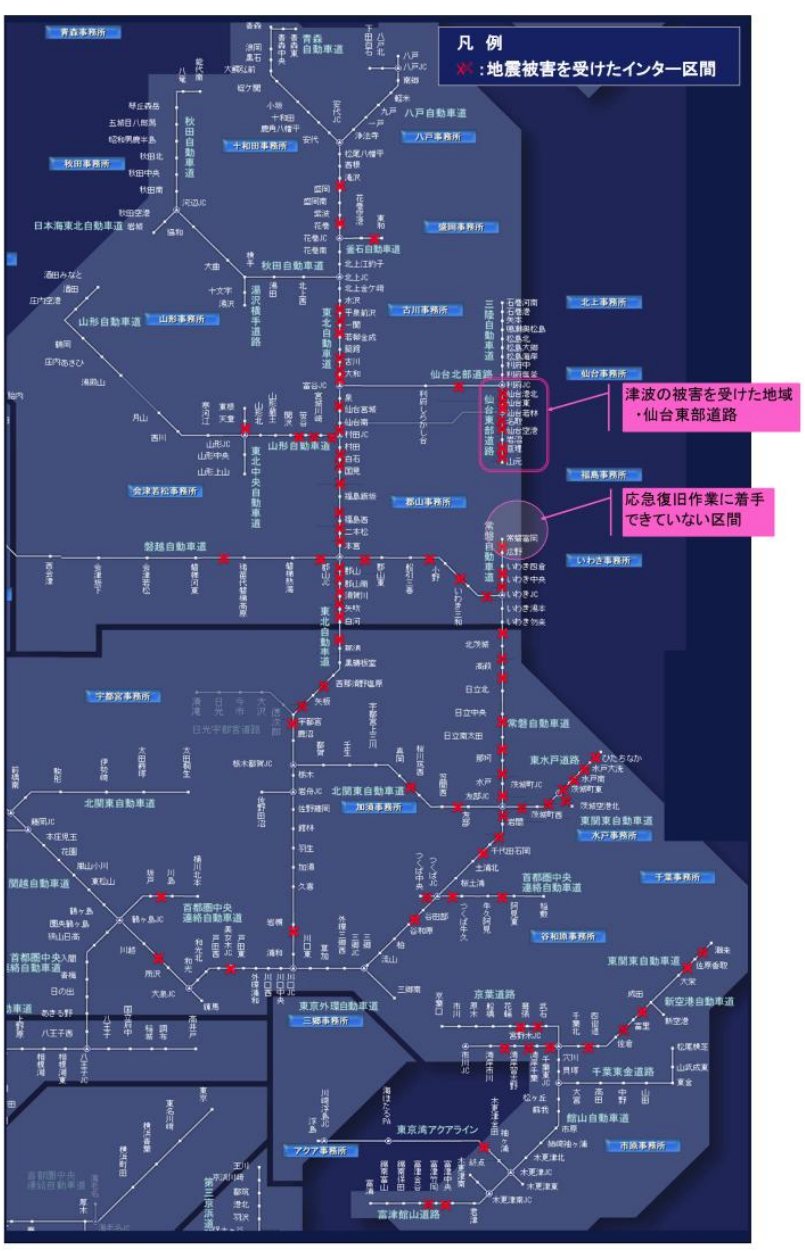

図 2 交通の障害となる被害を受けた路線・区間4)
表 4 交通の障害となる被害の発生状況 ${ }^{3)}$

\begin{tabular}{|c|c|c|}
\hline 路線名 & 延長 $(\mathrm{km})$ & 被害の状況 \\
\hline 東北自動車道 & 347.1 & 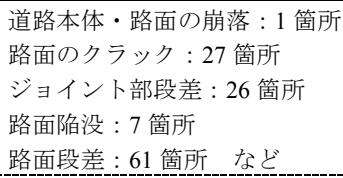 \\
\hline 磐越自動車道 & 85.5 & $\begin{array}{l}\text { 路面のクラック: } 13 \text { 箇所 } \\
\text { ジョイント部段差 : } 6 \text { 箇所 } \\
\text { 路面陥没 : } 4 \text { 箇所 } \\
\text { 路面段差 }: 5 \text { 䈯所 など }\end{array}$ \\
\hline 山形自動車道 & 28.1 & $\begin{array}{l}\text { ジョイント部段差: } 1 \text { 箇所 } \\
\text { 路面段差: } 5 \text { 籄所 }\end{array}$ \\
\hline 常磐自動車道 & 166.4 & 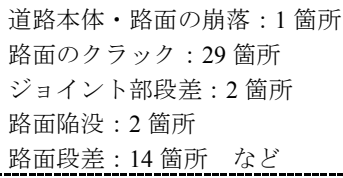 \\
\hline 仙台東部道路 & 18.5 & $\begin{array}{l}\text { 路面のクラック: } 1 \text { 箇所 } \\
\text { ジョント部段差 }: 7 \text { 箇所 } \\
\text { 路面陥没 }: 1 \text { 箇所 } \\
\text { 路面段差 }: 5 \text { 箇所 など } \\
\text { 津波による被害 }\end{array}$ \\
\hline その他の路線 & 224.2 & $\begin{array}{l}\text { 路面のクラック : } 27 \text { 箇所 } \\
\text { ジョント部段差 : } 14 \text { 箇所 } \\
\text { 路面陥没 : } 9 \text { 箇所 } \\
\text { 路面段差 : } 84 \text { 箇所 } \\
\text { 津波による被害 など }\end{array}$ \\
\hline 全 体 & 869.8 & $\begin{array}{l}\text { 道路本体・路面の崩落 : } 2 \text { 箇所 } \\
\text { 路面のクラック : 箇所 } \\
\text { ジョイント部段差 : } 56 \text { 箇所 } \\
\text { 路面陥没 : } 23 \text { 簀所 } \\
\text { 路面段差 : } 174 \text { 箇所 } \\
\text { 津波による被 など }\end{array}$ \\
\hline
\end{tabular}

\section{1 東北自動車道}

東北自動車道は, 川口 JCT〜青森 IC の間, 延長約 $680 \mathrm{~km}$

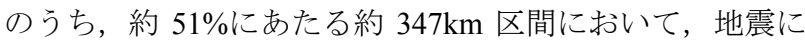
よる被害が発生した。震災後，幾度となく発生した余震の 影響で, 補修済みの大規模クラックが再度破損するといっ た事象も見られたが，白河 IC〜本宮 IC 間約 $53 \mathrm{~km}$ 区閒を 最後に，3 月 22 日までに全線で念急復旧が完了した。

\section{2 磐越自動車道}

磐越自動車道は，いわき JCT〜新潟中央 IC の間，延長 約 $213 \mathrm{~km}$ のうち，約 40\%にあたる約 $85 \mathrm{~km}$ 区間において, 地震による被害が発生したが，東北自動車道と接続する郡 山東 IC〜磐梯熱海 IC 間約 $16 \mathrm{~km}$ 区間を最後に，3 月 22 日 までに全線で応急復旧が完了した。

\section{3 山形自動車道}

山形自動車道は，村田 $\mathrm{JCT} \sim$ 月山 IC 間，延長約 $84 \mathrm{~km}$, のうち，約 34\%にあたる約 $28 \mathrm{~km}$ 区間において，地震によ る被害が発生したが，東北自動車道と接続する村田 JCT〜 笹谷 IC 間約 $22 \mathrm{~km}$ 区間を最後に，3 月 22 日までに全線で 応急復旧が完了した。

\section{4 常磐自動車道}

常磐自動車道は，三郷 JCT〜常磐富岡 IC 間，延長約 
$219 \mathrm{~km}$ のうち，約 $76 \%$ にあたる約 $166 \mathrm{~km}$ 区間において， 地震による被害が発生した。なお，この区間には，地震で 被害を受けるとともに, 福島県の原子力発電所事故の影響 など受けて通行行止めとなったいわき中央 $\mathrm{IC}$ 常磐富岡 IC 間約 $43 \mathrm{~km}$ 区間も含んでいる。常磐自動車道では，とく に，水戸 IC〜那珂 IC において，約 $130 \mathrm{~m}$ にわたり道路盛 土が崩落したが，この区閒を含む水戸 IC〜那珂 IC 間約 $12 \mathrm{~km}$ 区間においても，3 月 21 日までに応急復旧が完了し た。また, 原子力発電所の事故の影響などを受けて通行止 めとなっていたいわき中央 IC〜常磐富岡 IC 区間のうち, いわき中央 IC〜いわき四倉 IC 間約 $13 \mathrm{~km}$ の応急復旧が完 了したため，4 月 1 日に通行止めの解除を実施している。 その後，屋内避難指示解除に伴い，いわき四倉～広野間約 $14 \mathrm{~km}$ についても引き続き応急復旧を進め，4 月 28 日に通 行止めの解除を実施している。残る広野 IC～常磐富岡 IC 間約 $16 \mathrm{~km}$ 区間については，福島原発の事故に伴う避難指 示区域などに含まれており応急復旧作業に着手できない ことから, 本報文執筆時点では通行止め解除の見通しは立 っていない。

\section{5 その他の路線}

仙台東部道路は，仙台若林 JCT〜仙台港北 IC 間約 $10 \mathrm{~km}$ 区間において，また，三陸自動車道は，仙台港北 $\mathrm{IC} \sim$ 利 府 JCT 間約 $4 \mathrm{~km}$ 区間において，地震の影響に加え，太平 洋沿岸に位置するため，津波による被害が発生した。しか しながら，これら路線も，3 月 30 日までに全線で応急復 旧が完了している。

なお，応急復旧が完了した区間について，引き続き，順 次, 計画的に本復旧が実施されている。

\section{5. 土工部の被害状況}

今回の東北地方太平洋沖地震において, 高速道路で比較 的多く発生した土工部の被害状況について, 以下に示す。

\section{1 盛土部の被害}

東北地方太平洋沖地震による土工部の被害の中でも，も っとも顕著に見られた被害が盛土部の被害である。高速道 路の通行に影響を与える盛土崩落が，表 5 に示すとおり， 21 箇所で発生している。

以下に，とくに，盛土崩落が大きかった箇所について， 具体的な被害状況を示す。

\subsection{1常磐自動車道那珂（なか）地区盛土部崩落箇所}

茨城県那珂市市内の常磐自動車道での盛土崩落は, 那珂 IC から東京方面に向かって約 $1.2 \mathrm{~km}$ あたりの上り線 92.4KP 付近で発生した。被害状況は, 盛土のり面中腹部 から上側ののり面が崩落しており，崩落延長は約 $130 \mathrm{~m}$, 道路縦断方向に沿って最大 $2 \mathrm{~m}$ 強の段差が生じた(写真 2 , 図 3)。特筆すべき事項としては, 走行車線と追越車線の 境, 走行車線と路肩との境, 路肩部の情報管路埋設跡付近 といった舗装の打継ぎ目にあたる部分を境に段差や亀裂
が入り，盛土が崩落しているような状況が確認された。

表 5 本線に影響を与える盛土崩落発生箇所一覧表

\begin{tabular}{|c|c|c|c|c|c|}
\hline 番号 & 路線名 & 区間 & 区分 & KP & 備考 \\
\hline 1 & 仙台北 & 利府しらかし台 & 上下 & $8.9 \sim 9.1$ & \\
\hline 2 & 部道路 & ～富谷 JCT & 上下 & $8.9 \sim 9.1$ & \\
\hline 3 & 山形道 & 村田 JCT 宮城川崎 & 上 & 6.6 & \\
\hline 4 & \multirow{16}{*}{ 東北道 } & 泉～富谷 JCT & 下 & 348.2 & \\
\hline 5 & & 福島飯坂～国見 & 下 & 274.7 & 崩落大 \\
\hline 6 & & \multirow{2}{*}{ 白河～矢吹 } & 上 & 178.0 & \\
\hline 7 & & & 上 & $180.3 \sim 180.4$ & \\
\hline 8 & & \multirow{7}{*}{ 矢吹～須賀川 } & 上 & 187.5 & \\
\hline 9 & & & 上 & 188.7 & \\
\hline 10 & & & 上 & $193.2 \sim 193.3$ & \\
\hline 11 & & & 上 & 193.2 & \\
\hline 12 & & & 下 & 194.6 & \\
\hline 13 & & & 下 & 197.6 & 崩落大 \\
\hline 14 & & & 上 & 196.5 & \\
\hline 15 & & \multirow{4}{*}{ 須賀川 〜郡山南 } & 上 & 201.4 & \\
\hline 16 & & & 下 & 201.5 & \\
\hline 17 & & & 上 & 201.5 & \\
\hline 18 & & & 下 & $204.2 \sim 204.3$ & \\
\hline 19 & & 郡山 JCT〜本宮 & 上 & 222.3 & \\
\hline 20 & 磐越道 & 郡山東〜郡山 JCT & 上 & $69.8 \sim 70.3$ & \\
\hline 21 & 常磐道 & 水戸〜那珂 & 上 & 92.5 & 崩落大 \\
\hline
\end{tabular}

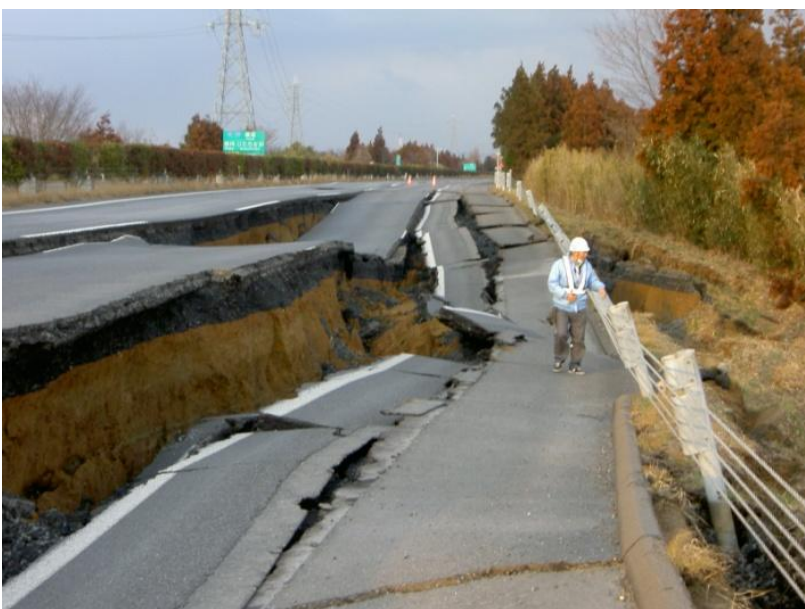

写真 2 常磐自動車道那珂地区盛土崩落箇所の状況 ${ }^{4)}$ （図面奥 : 宮城方面，図面手前：東京方面）

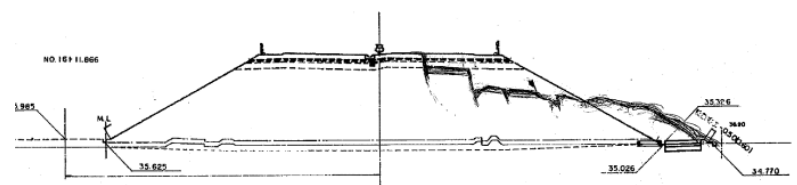

図 3 常磐自動車道那珂地区盛土崩落箇所の横断図 (図面奥 : 宮城方面, 図面手前 : 東京方面)

現在，当盛土が崩落した原因について調査しているが， 応急復旧時の状況によると, 盛土の含水比が比較的高く, 手で握ったら水が絞れるような状況だったことが明らか となっている（写真 3)。両側にのり面があるといった, 一般的に水の供給が想定しにくい盛土形状であり, 含水比 が高いことなどを含め，原因の究明を行っていく。なお， 中越地震の際は, 台風通過直後であったために被害が大き かったとみられるが，今回は，降雨の影響は少ないと思わ れる。 


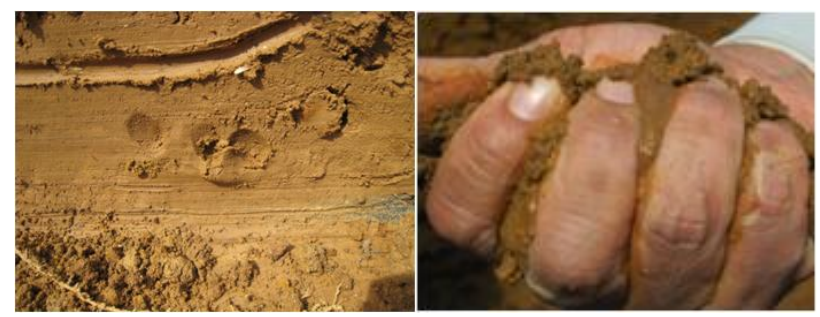

写真 3 応急復旧時の既設盛土の盛土材の状況

\subsection{2 東北自動車道須賀川地区盛土部崩落箇所}

福島県須賀川市市内の東北自動車道での盛土崩落は, 須 賀川 IC から東京方面に向かって約 $0.5 \mathrm{~km}$ あたりの上り線 197.6KP 付近で発生した。崩落箇所は，ちょうど一級河川 䣋迦堂川にかかる本線橋梁の橋台背面部にあたる。崩落状 況は, 橋台背面部の路肩部分の舗装が陥没するような形で 発生しており, 崩落延長約 $90 \mathrm{~m}$, 陷没した箇所の陷没深さ が約 $1 \mathrm{~m}$ であった。陥没した路肩の外側ののり面にも変状 が生じており, 橋台前面の河川護岸のり面にも変状がつな がっていた（写真 4, 図 4)。

現在，当盛土が崩落した原因について調査しているが， 当箇所の過去の土地利用を確認したところ, 1964 年では, 一級河川釈迦堂川は現在の河道線形に比べ, かなり蛇行し た河道線形であり，被害箇所は，旧河道脇であったことが 明らかとなっている (写真 5,6)。現在, その影響を含め, 原因の究明を行っている。

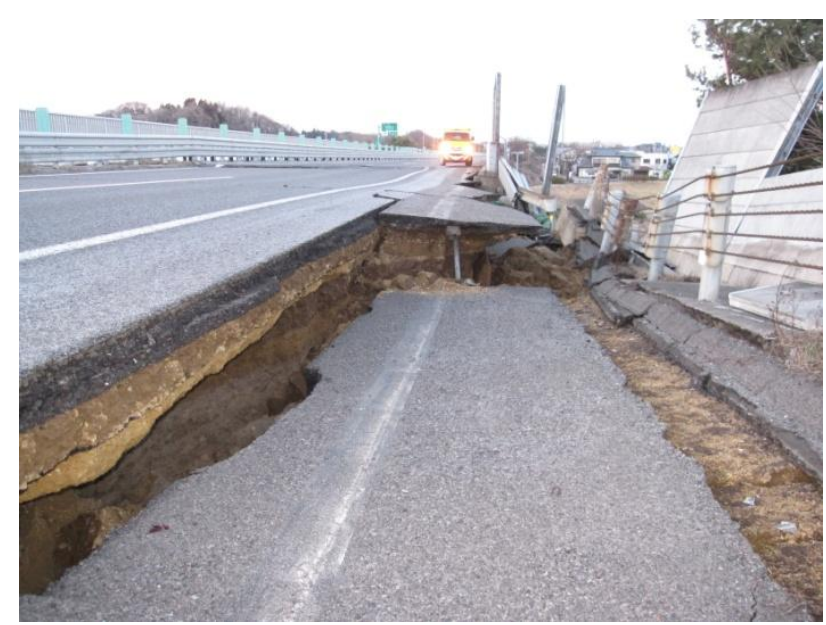

写真 4 東北自動車道須賀川地区盛土崩落箇所の状況 ${ }^{4}$ (図面奥 : 青森方面，図面手前 : 東京方面)

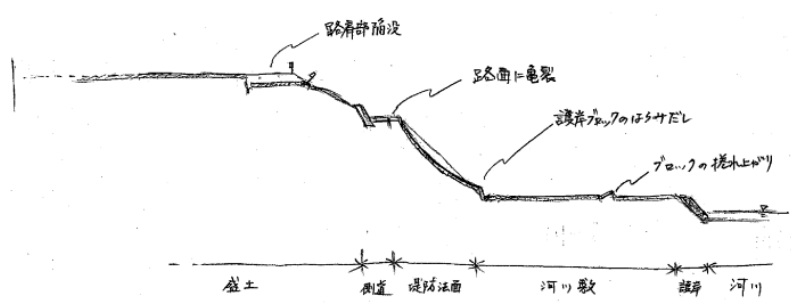

図 4 東北自動車道須賀川地区盛土崩落䇢所の状況 (図面奥 : 青森方面，図面手前 : 東京方面)

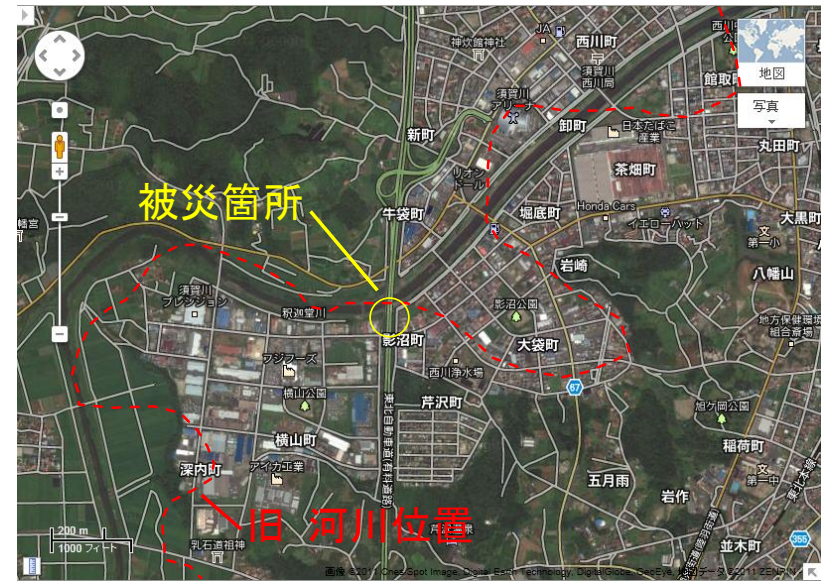

写真 5 東北自動車道須賀川地区盛土崩落箇所航空写真 5 (加筆 (2011年撮影)

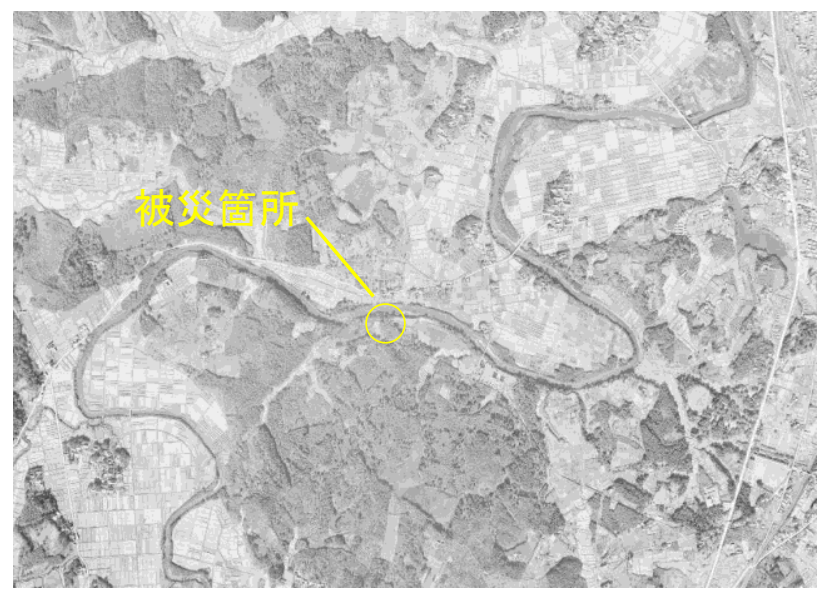

写真 6 東北自動車道須賀川地区盛土崩落箇所航空写真6)飞加等 (1964年撮影)

\subsection{3東北自動車道国見地区盛土部崩落箇所}

福島県伊達郡国見町町内の東北自動車道での盛土崩落 は，国見 IC から東京方面に向かって約 $1.3 \mathrm{~km}$ あたりの下 り線 274.7KP 付近で発生した。崩落状況は, 走行車線上に 開き幅最大 $80 \mathrm{~cm}$ 程度の亀裂が生じ，路肩部が若干沈下す るような状況になっていた（写真 7, 図 5)。ただし，崩 落側の舗装版全体が沈下寸るような状況にはなっていな い。破断した舗装版は，のり肩方向に移動するような状況 を示している。また, 舗装が移動した側ののり尻付近の原 地盤（水田）に隆起や側方移動，噴砂の跡が見られた。被 害箇所の航空写真を見てみると, 高速道路本線脇の水田に しわのような跡が確認できる（写真 8)。

現在, 当盛土が崩落した原因について調査しているが, 周辺地盤の液状化が影響を与えているものと推測してい る。その影響を含め，原因の究明を行っている。 


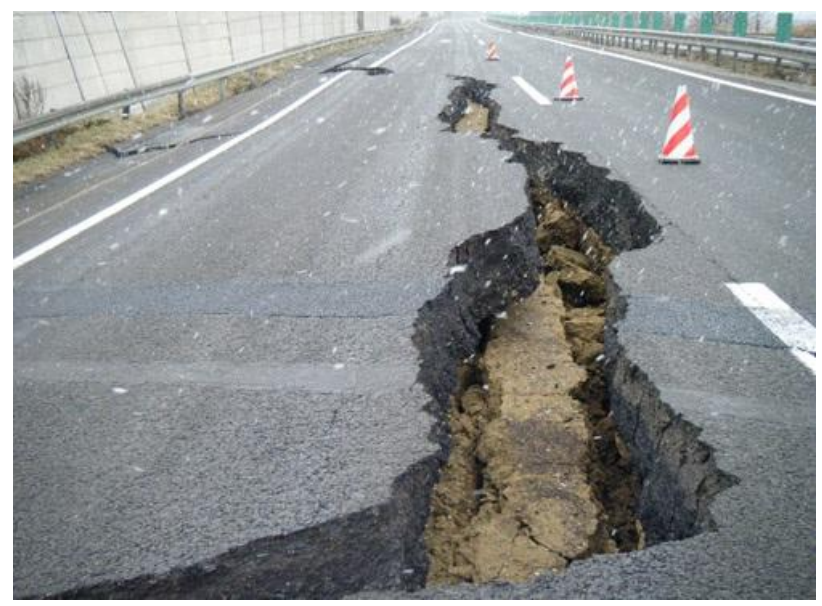

写真 7 東北自動車道国見地区盛土崩落箇所の状況 (図面奥 : 青森方面, 図面手前 : 東京方面)

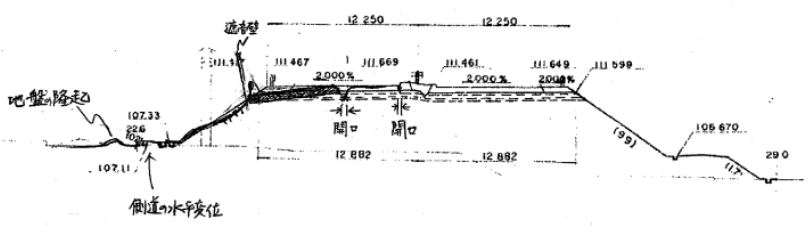

図 5 東北自動車道国見地区盛土崩落箇所横断図 (図面奥 : 青森方面，図面手前 : 東京方面)

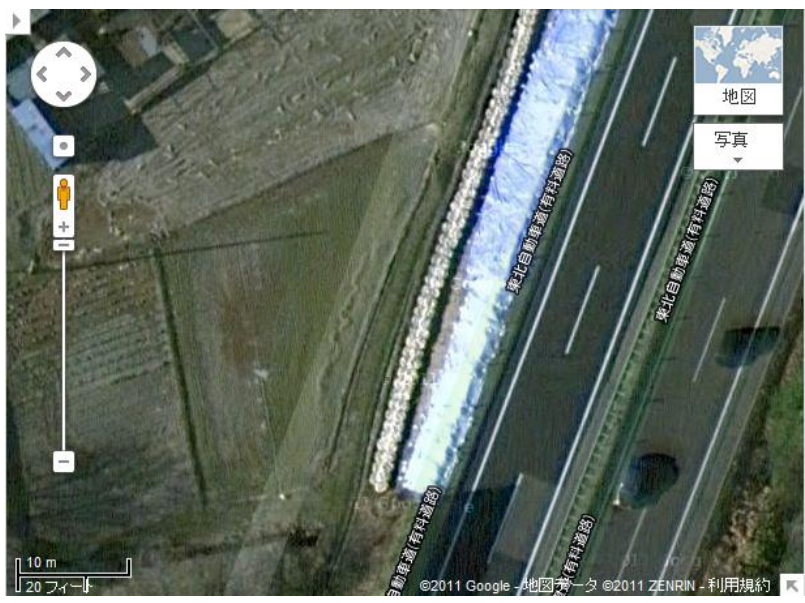

写真 8 東北自動車道国見地区盛土崩落箇所の状況 ${ }^{52}$ 飞加筆

\section{2 切土部の被害}

これまで過去に発生した地震において, 高速道路の切土 のり面が，地震により崩落して車線を埋めたというような 事例はない7)。今回の 3 月 11 日に発生した東北地方太平洋 沖地震においても，これまでと同様，切土のり面が大崩落 したといった事象は発生していない。しかしながら，4月 11 日に発生した東北地方太平洋沖地震の大規模な余震(震 源 : 福島県浜通り, 震源の深さ: 約 $6 \mathrm{~km}$, マグニチュード : 7.0, 最大震度 : 6 弱) において, 高速道路では, 初めて, 大規模な切土のり面の崩落が発生した。以下にその概要を 示す。

\subsection{1常磐自動車道いわき地区切土部崩落箇所}

東北地方太平洋沖地震発生後の同年 4 月 11 日発生した
福島県浜通りを震源とする大規模な余震の発生に伴い, 常 磐自動車道いわき勿来（なこそ）IC〜いわき湯本 IC 間に おいて，下り線側の切土のり面が崩落し，一部，上り線側 の車線まで到達するという切土のり面の大規模な崩落が 発生した（写真 9, 図 6)。

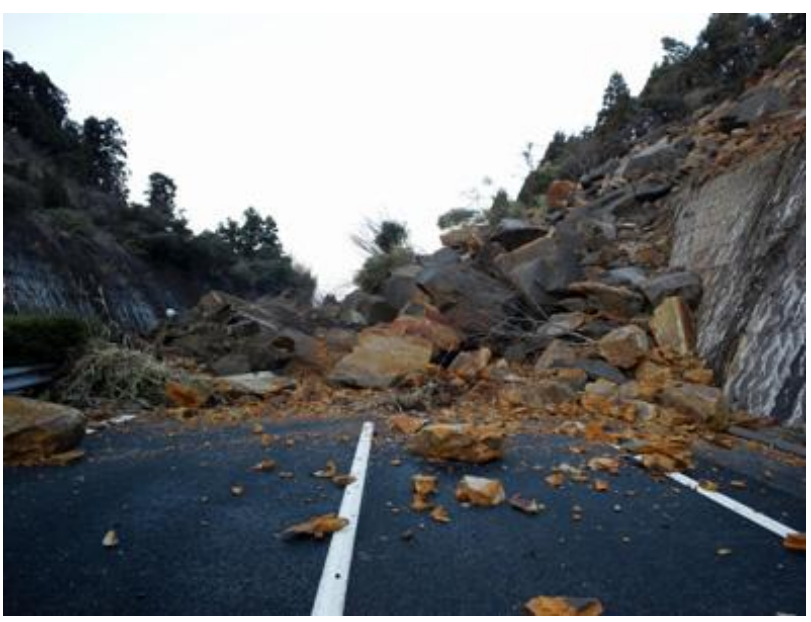

写真 9 常磐自動車道切土のり面崩落の状況 ${ }^{8}$ (写真奥 : 東京方面，写真手前 : 宮城方面)

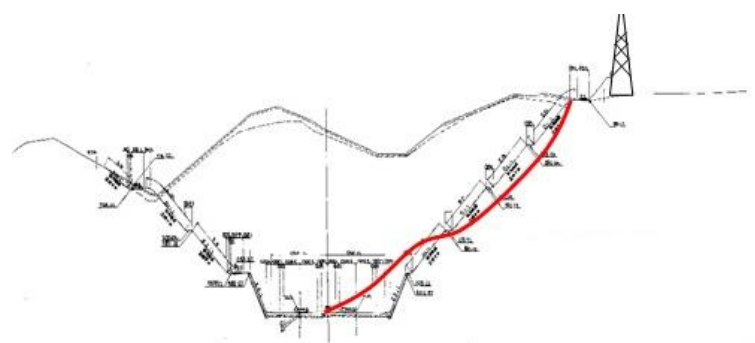

図 6 切土のり面崩落箇所横断図 ${ }^{8)}$ (写真奥 : 東京方面，写真手前 : 宮城方面)

崩落箇所の路面は, 道路縦断方向に約 $50 \mathrm{~m}$, 道路横断方 向に約 $15 \mathrm{~m}$ にわたって崩落堆積物で埋め尽くされ，堆積 物の最大堆積高さは約 $8 \mathrm{~m}$ にもなった。崩落は，道路面よ り約 $35 \mathrm{~m}$ の高さにある切土のり面の頂部を上端として発 生していた。また，その頂部には送電線の鉄塔があったこ とから，この崩落に伴い，鉄塔の基礎の一部が露出した。 原因については，現在，調査中だが，切土のり面頂部の 上部の鉄塔の基礎杭前面の斜面の風化に起因するものと 推測している。地質性状も含め, 原因の究明を行っている。

\section{3 液状化による被害}

液状化による被害についても，切土部の被害と同様，こ れまで過去に発生した地震において，高速道路の土工部が 液状化により大きく被害を受けたという事例はないとさ れている。今回の東北地方太平洋沖地震においても, これ までと同様, 液状化による高速道路の土工部での大きな被 害は発生しなかった。しかしながら，東関東自動車道の潮 来 IC 付近の側道部において，液状化によると思われる被 害が発生したので，以下にその概要を示す。 


\subsection{1東関東自動車道潮来地区液状化被害箇所}

茨城県潮来市市内の東関東自動車道での液状化による 被害は, 潮来 IC から東京方面に向かって約 $1.0 \mathrm{~km}$ あたり の上下線 73.6 73.7 KP 付近で発生した。被害の状況は, 高速道路本線部は, 下り線側の盛土のり面が小崩落したほ か路面が一部沈下した程度で，大きな被害ではなかった (写真 10)。

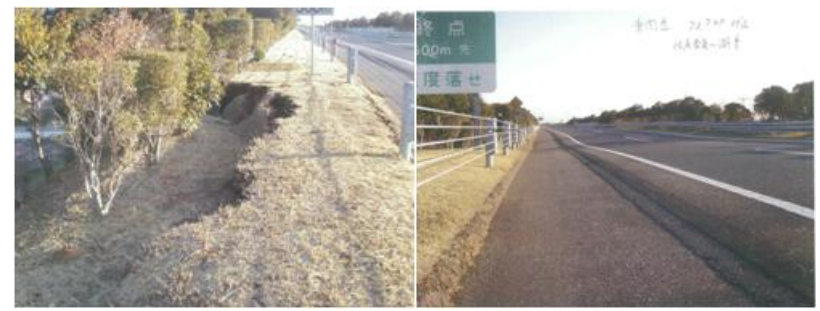

写真 10 東関東自動車道潮来地区液状化被害状況 (高速道路下り線本線部)

しかし, 高速道路本線脇の側道部においては, 路面に大 きく亀裂が入り, 沈下と隆起が生じ, 高速道路本線の盛土 ののり尻が側道側に大きく流れ出す形で側方流動してい た。また，周辺の水田では，噴砂や噴水の跡が確認される など，液状化特有の現象が確認された（写真 11）。液状化 被害箇所の過去の土地利用を確認したところ, 昭和 22 年 には，鯰（なまず）川と呼ばれる小河川が横断しており， その後の戋場整備に伴い, その小河川は埋め立てられたこ とが確認された（写真 12）。改めて, 震災後の液状化被害 箇所周辺の航空写真を見ると, 旧河道跡に沿って, 噴砂 ・ 噴水と見られる跡が確認できる（写真 13）。

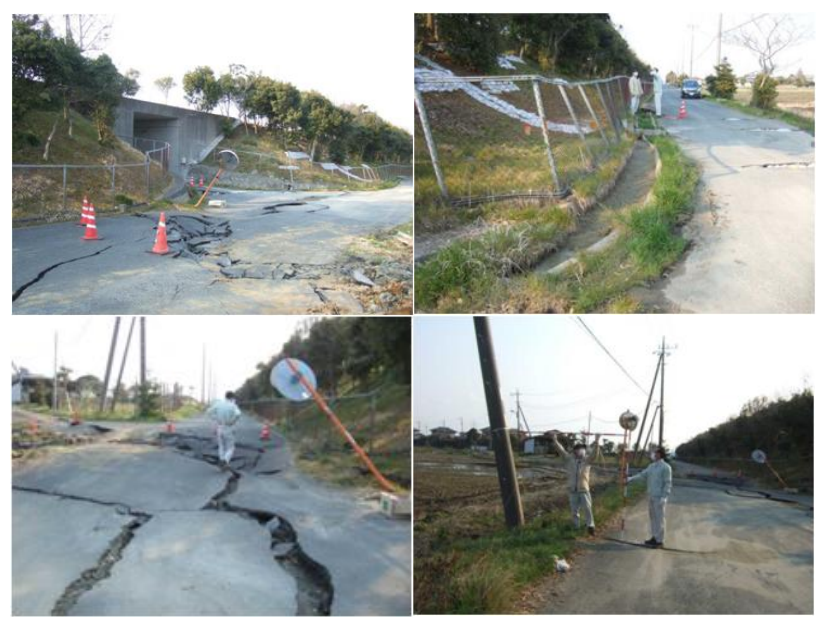

写真 11 東関東自動車道潮来地区液状化被害状況 （高速道路上り線本線脇側道部）

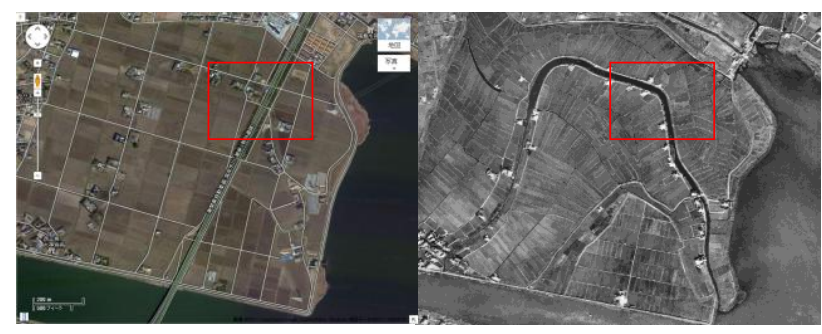

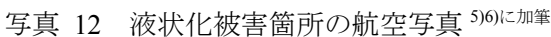

（赤枠が被害箇所，写真左 : 2011 年撮影，写真右：1947 年撮影)

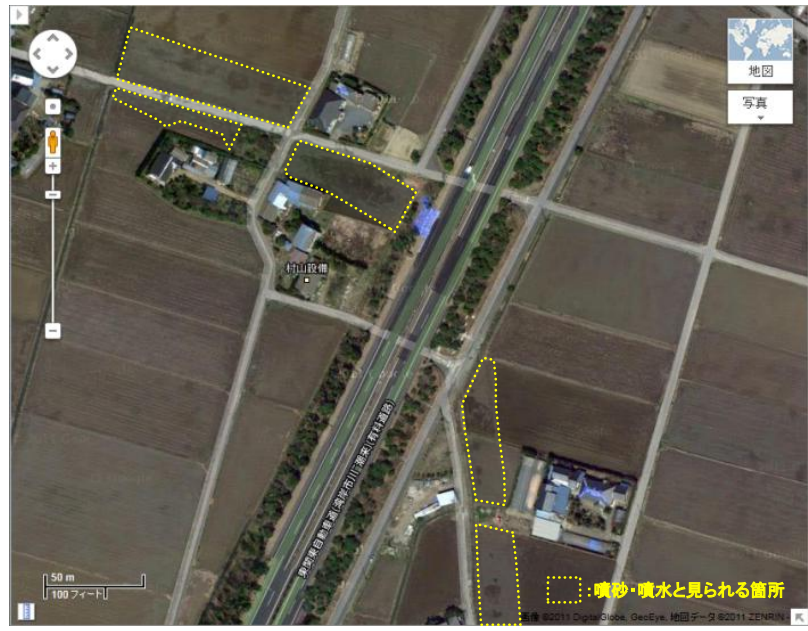

写真 13 液状化被害箇所の航空写真 5 )《加篻

(写真 12 の赤枠内，震災直後に撮影）

\section{4 その他の被害}

今回の地震においては, 太平洋側に面した海岸部や平野 部においても甚大な被害が出ているが, 東北地方太平洋沖 地震が引き金となって発生した大津波により, 三陸自動車 道や仙台東部道路の IC 付近において, 浸水やがれきの堆 積などの被害が発生した（写真 14，15，図 7)。仙台東部 道路名取 IC 付近の高速道路本線では, 約 230 名の地域住 民が津波から避難されたことが，後に明らかとなっている。

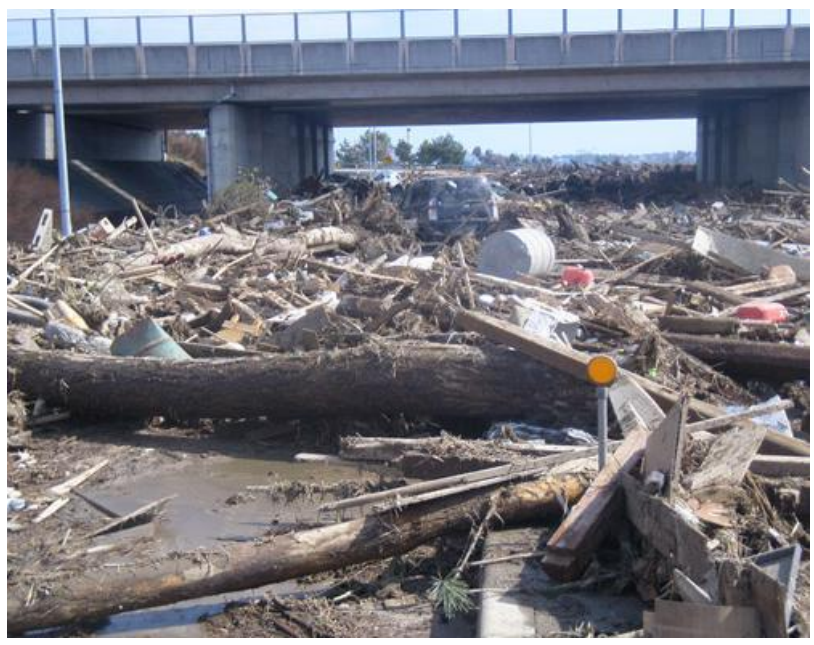

写真 14 津波による被害状況9

(仙台道部道路若林 JCT 上下線ランプ部) 


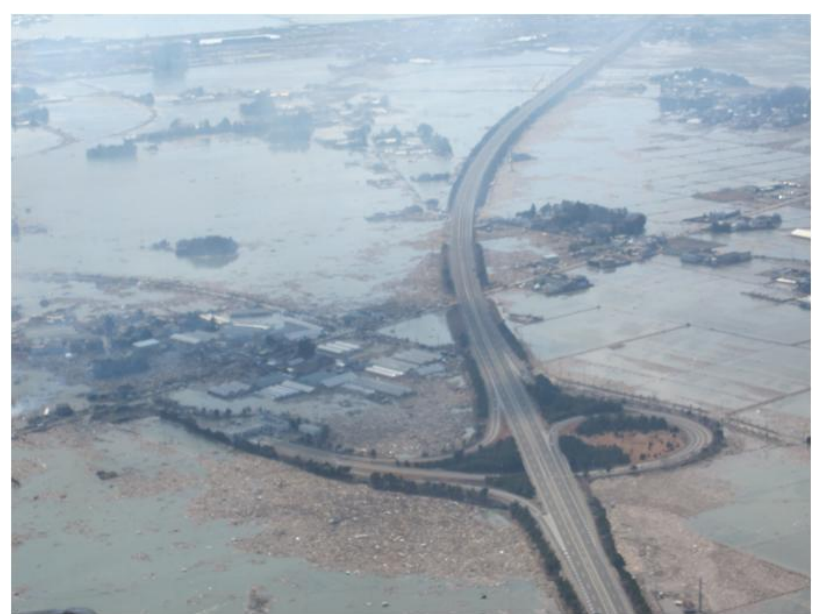

写真 15 津波による被害状況（仙台東部道路名取 IC) (写真左手 : 海側, 写真右手 : 陸側)

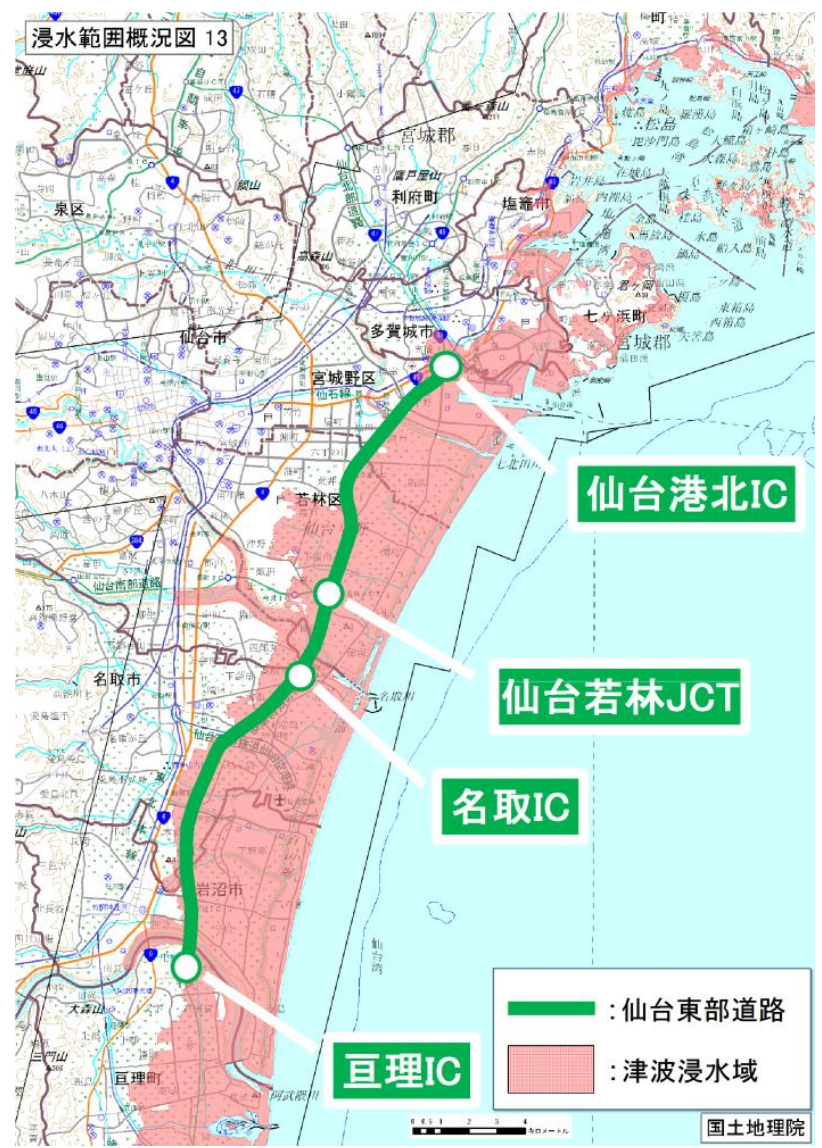

図 7 仙台東部道路付近の津波による浸水範囲概要図 10 )加筆

\section{6. おわりに}

今回の東北地方太平洋沖地震による高速道路の土工部 の地震被害の状況を踏まえ, 以下に, 特筆すべき点を挙げ る。

1）地震の規模は非常に大きかったが, 大きな被害は少 なかった。ただし，比較的盛土高の低い盛土でも被 害が発生していた。

2）土工部と構造物（橋台やボックスカルバートなど） との境での段差が多く発生した。
3）地域により地震被害が集中しているところがあっ た。とくに，窪地や谷底平野で河道のあるところ， ため池埋め立て地, 盛土下のボックスカルバートか ら湧水が見られるようなところで，比較的多く，盛 土の被害が発生していた。

4）片側 2 車線の 4 車線の高速道路では，少なくとも， 片側 2 車線の機能が残り, 震災後の緊急車両の交通 路や復旧工事の工事用道路として活用された。

1）は，とくに，東北自動車道においては，高盛土が少 なく, 比較的低盛土の区間が多いことに起因すると思われ る。また，同じように土工部での被害が多かった中越地震 と比較した場合, 今回の地震は地震の規模こそ大きかった が，大きな被害は少なかった。これは，中越地震では地震 発生前に台風が通過していたことに起因するものと思わ れる。ただし，これまであまり被害が多くなかった低盛土 で被害が多かったのは, 地震動の継続期間が長かったこと と, また，余震が多かったこととに起因するものと思われ る。2）についても，1）同様，地震動の継続期間が長かっ たことと, また, 地震の周期が短かったことなど, これま での地震とは少し特徴の違う地震だったことに起因する ものではないかと考える。3）については，今回の地震に よる被害要因が，地盤や地質の影響によるものか，盛土材 料や施工の影響によるものか，さらには，過去の土地利用 をも含め，マクロ的な視点で分析を進めている。4）は， 今後の防災の知見として, 災害を限定的に留めることが重 要であることを示唆しているものと考える。

最後に，今回の東北地方太平洋沖地震では，広範囲にお いて被害が発生したが, 想定を上回るような大きな被害は 発生していない。現在，比較的規模の大きい被害の原因に ついて究明中であるが，今のところ，新たな知見を得るに 至っておらず, 既設盛土の耐震性強化としては,「のり尻 の強化」や「盛土内の排水処理の強化」というこれまでの 方針に変更はない。とくに，第三者被害が想定される場所 を優先に, 排水対策を主体とした既設盛土の強化対策を実 施していく。

\section{参 考 文 献}

1) 東日本高速道路株式会社, 新潟県中越地震 災害報告書《高速道 路の被災から復旧までの軌跡》，p.26，2006.9.

2) 地震調查研究推進本部, 震源・震度に関寸る情報, http://www.jishin.go.jp/main/p chousakansoku03.htm

3) 東日本高速道路株式会社, 定例記者会見資料, 別紙 p4 7, 2011.3.24

4) 東日本高速道路株式会社, 東北地方太平洋沖地震による高速道路 の被害と復旧状況について，本社プレスリリース，別紙 $\mathrm{I}-1-2$, 別紙 I-1-3，2011.3.18.

5) Google マップ.

6) 国土地理院，国土変遷アーカイブ空中写真.

7) 望月 秀次ら，高速道路の被害と復旧の考え方，基礎工，Vol.33， No.10, pp.33-38, 2005

8) 東日本高速道路株式会社，（第6報）福島県浜通り地方を震源とす る地震に伴う高速道路の状況について, 東北支社プレスリリース, 2011.4.12.

9) 東日本高速道路株式会社，（第12報）東北地方太平洋沖地震に伴 う高速道路の状況について（東北支社），東北支社プレスリリー ス, 2011.4.12.

10) 国土地理院，10万分 1 浸水範囲概況図，平成23年（2011年）東日 本大震災に関する情報提供,

http://www.gsi.go.jp/common/000060133.pdf, 2011.4.18.

(2011.12.8 受付) 


\title{
Damages and recovery of expressways affected by the Off the Pacific coast of Tohoku Earthquake
}

\author{
Tetsuo $\mathrm{ABE}^{1}$, Seiya YOKOTA ${ }^{2}$, Kazuo KANETA ${ }^{3}$ and Kazuyuki NAGAO ${ }^{4}$ \\ 1 Nippon Expressway Research Institute Company \\ 2 Nippon Expressway Research Institute Company \\ 3 East Nippon Expressway Company \\ 4 Nexco-East Engineering
}

\begin{abstract}
Around 14:46 on March 11, 2011, a magnitude 9.0 earthquake, the largest in our country's history was recorded off the coast of the Sanriku area in the Tohoku region. A seismic intensity of 7 was observed in Kurihara, Miyagi Prefecture and strong tremors were felt in a wide area from the Tohoku to Kanto region, A maximum seismic intensity of 6.3 was observed at Mito-Minami IC on the Kita-Kanto Expressway. After the quake, emergency inspections were carried out on expressways and it was identified that damages may obstruct traffic on 20 routes for some $870 \mathrm{~km}$. However, owing to the efforts of officials and worker, Tohoku Expressway, Joban Expressway and Ban-etsu Expressway, were opened to emergency vehicles by 11:00 a.m. on March 24, about 20 hours after the earthquake. And Tohoku Expressway was completely opened, except for a few sections, at 6:00 a.m. on Marth 24, 13 days after the quake. This paper reports on the damages and recovery of the earthwork portion of the expressways affected by "The Off the Pacific coast of Tohoku Earthquake".
\end{abstract}

Key words: Off the Pacific coast of Tohoku Earthquake, highway, earth work, seismic damage, embankment 